\title{
INNOVATION TYPES AND SALES GROWTH IN SMALL FIRMS: EVIDENCE FROM KOSOVO
}

Lura Rexhepi Mahmutaj, Besnik Krasniqi

\section{Abstract}

The purpose of this paper is to investigate the impact of different forms of innovation on firm growth, in terms of sales. A total of 278 samples were collected from SMEs in the manufacturing, service and trade industries throughout Kosovo. The data were analysed using a logistic regression analysis. The findings confirm the hypotheses that marketing innovation is positively associated with firm growth, while new to the firm products is negatively associated with firm growth. Other innovation attributes have resulted with non-significance value. The findings in this study can be useful for theoretical discussion, as well as for policy formulation related to introduction of innovation and SMEs development considering that innovation is critical factor in today's market and competition. Further studies should look into how SMEs could investigate over time from the initial stage to the full development of innovation.

Keywords: Small and Medium Enterprises, innovation, firm growth, Kosovo

JEL Classification: L25, L26, O31

\section{INTRODUCTION}

The Republic of Kosovo is the newest state in Europe, and it is still one of the poorest countries in Europe with a very solid economic growth performance since the end of the war (World Bank 2013). Kosovo, like many other economies, is dominated by Small and Medium Enterprises (SMEs). SMEs in Kosovo constitute more than $98 \%$ of the total number of firms and they operate mostly in the sectors of trade and services, followed by manufacturing (Krasniqi 2012). The importance of entrepreneurship and the SME sector is tremendous representing the majority of employment, income, and output. Despite its importance, the innovation as a driver for competitive advantage is still a new and emerging concept among SMEs in Kosovo (MTI 2013).

Considering the large contribution of the SME sector to the economy (Jutla et al. 2002; Singh et al. 2010), SMEs' competitiveness must be sustained over time.
Lura Rexhepi Mahmutaj, PhD

(corresponding author)

Teaching Assistant

Faculty of Economics

Department of Management and Informatics

University of Prishtina "Hasan Prishtina"

Email: lura.rexhepi@uni-pr.edu

Address: Rr. Agim Ramadani, pn. Prishtine, 10000,

Kosovo

Besnik Krasniqi, PhD

Associate Professor

Faculty of Economics

Department of Management and Informatics

University of Prishtina "Hasan Prishtina"

Email: besnik.krasniqi@uni-pr.edu 
SMEs are searching for new ways to introduce innovation activities to achieve growth (Pullen et al. 2009). One of their most important characteristics, which is seen as a core competence is their flexibility, meaning that they can change direction rapidly or the ability to do something else from which was originally intended (Evans, 1991; Storey 1994). It is argued that because of entrepreneur independence, SMEs are associated with a high degree of creativity, enabling them to exploit new ideas and resources for organizational growth (Wilson and Stokes 2005). Moreover, SMEs have less formalized governance and management arrangements. It is the owner, which is usually the same as the CEO, who is involved in all strategic decisions for the firm (Gao and Hafsi 2015). Nevertheless, SMEs are characterized by scarce resources, which can interfere with innovation development. Woschke et al. (2017) explored the effects of resource scarcity on innovation by using the panel data of 302 SMEs. Their results indicate that resource scarcity has a positive effect only on incremental innovation, compared to radical innovation performance in SMEs. All these characteristics of SMEs show that they are capable of developing innovation activities which are about introducing new ways for products, services, production, marketing, and administration, which are difficult to imitate, to gain a competitive advantage in this dynamic environment. Thus, innovation is a necessity rather than a luxury and should be treated with care within firms to achieve growth (Kaplan and Warren 2007).

This study contributes to a better understanding of SMEs growth and innovation because SMEs are characterized by resource scarcity, flexibility, and high risk of failure due to the dynamic environment, especially in transition environments like Kosovo, which are associated with more frequent changes in the business environment. The literature on the impact of different types of innovation on firm growth is not conclusive; and many authors have been focused only on one or two dimensions, such as product and process innovations (Lee et al. 2010). This paper will address the importance of all innovation types such as product/ process, marketing and organizational innovations on SMEs' growth.

For the sake of knowledge development, this study aims to examine different types of innovations to support higher firm growth performance in more detail with a specific focus on SMEs in the Kosovo market. The sectors for this study include manufacturing, services, and trade. The structure of the paper is as follows. The second section puts forward a conceptual model that links types of innovation and SMEs growth in terms of sales. The third section provides details on the research methodology, including data collection and measurements of dependent and independent variables. The fourth section tests the conceptual model through the logistic model and presents the results and discussion. Implications for research and practice are articulated. The paper provides a conclusion and implications for research and practice. It also provides suggestions on how to address the limitations.

\section{LITERATURE REVIEW}

\section{Types of innovations}

Innovation is "the implementation of a new or significantly improved product (good or service), or process, a new marketing method, or a new organizational method in business practices, workplace organization or external relations" (OECD 2005). Innovation can be radical or incremental, and most of the authors classify it as products, processes, marketing and organizational innovation (OECD 2005; Oke et al. 2007; Chetty and Stangl 2010).

Previous studies did not analyse the degree of innovation. As long as a new product was introduced, it was considered an innovation. Nevertheless, the research differentiates product innovation by adopting incremental or radical changes (Salavou and Lioukas 2003), depending on the degree of change of innovation, as well as its perceived risks. The difference is that radical innovation produces fundamental changes within organization (North and Smallbone 2000; Chetty and Stangl 2010), and often create demand not recognized by customers (Garcia and Calantone 2002), while incremental one has to do with improvement in the existing methods, practices, and capabilities of organizations (Dewar and Dutton 1986; North and Smallbone 2000; Chetty and Stangl 2010), or new features and benefits to existing market (Garcia and Calantone 2002). Furthermore, OECD (2005) stressed out the degree of novelty in terms of new to the firm, new to the market and new to the world. A minimum entry level of innovation is that it should be new to the firm, which means when an innovation has been implemented by other firms, but it is new to the firm. Moreover, new to the market innovations is when a firm is the first to introduce an innovation to the market, which may include both domestic and international firms. New to the world innovations have the greatest degree of novelty, which involves innovation first implemented in all markets and industries, either domestic or international (OECD, 2005). Innovations in SMEs are usually incremental, or new to the firm, as they are characterized by limited resources in capital, 
personnel, and technology (Storey 1994; Woschke et al. 2016). Therefore, the discussion leads to this hypothesis:

\section{Hypothesis 1: Introducing new to the firm prod- ucts is positively associated with sales growth.}

\section{Product, Process, Organization \& Marketing innovations}

Product innovation can be defined as new or alteration of existing products and services which lead to higher sales or meeting customers' satisfaction (Oke et al. 2007; Langley et al. 2005; Chetty and Stangl 2010). Significant change can happen when firms implement single innovation, or series of incremental changes (OECD, 2005), which can create new markets or customers, or satisfy current ones (Wan et al. 2005). Moreover, process innovation is about new methods of production or delivery (Oke et al. 2007; Chetty and Stangl 2010). It is about the improvements made in technical design, R\&D, manufacturing, management and commercial activities (Freeman 1982). Organizational innovation has to do with management initiatives, which refers to the implementation of new organizational methods in the business practices, workplace organization or external relations, leading to labour productivity. Also, marketing innovations include product design or packaging, placement, pricing, promotion or positioning strategies leading to positive changes (Oke et al. 2007; Chetty and Stangl 2010).

\section{The relationship between SMEs growth and Innovation}

A large number of studies have been focused relationship between innovativeness and firm performance, which conclude that innovative firms achieve superior performance and competitive advantage (Damanpour and Evan 1984; Deshpande et al. 1993; McGrath et al. 1996; Han et al. 1998; Hult and Ketchen 2001; Calantone et al. 2002; Garg et al. 2003). Nevertheless, these studies focus on only one type of innovation, and it can be concluded that process and product innovation have been mostly examined. The studies by Ittner and Larcker (1997), Knott (2001), Baer and Frese (2003) and Yang (2010) focus merely on process innovations while studies of Atuahene-Gima (1996), Subramanian and Nilakanta (1996), Han et al. (1998) and Li and Atuagene-Gima (2001) report on product innovations. Nevertheless, some studies indicate a negative relationship or no link at all between innovations and firm performance (Chandler and Hanks 1994; Subramanian and Nilakanta 1996). Hence, there are not many studies related to marketing and organizational innovations, which are essential to firm growth (Gunday et al. 2011).

The influence of product innovation on business performance has gained interest among the authors in recent literature. Several studies conclude that product innovation has a positive relationship with organizational performance. Rosli and Sidek (2013) confirm that product and process innovation have an impact on organizational performance. Bayus et al. (2003) proved that product innovation has a significant link to business performance based on the study of the personal computer industry, being one of the most innovative sectors. Another empirical study introduced by manufacturers in the United Kingdom from 19451983 of Geroski et al. (1993) concludes that product, process, and material innovation have a positive effect on profit margins. Moreover, Hernandez-Espallardo and Delgado-Ballester (2009) in a study conducted with manufacturing Spanish SMEs confirmed a positive and significant relationship of innovation on organizational performance. The study performed with SMEs in Finland also concludes a positive relationship between product, process and market innovations with organizational growth, but interestingly there was no relationship found between organizational innovation and organizational growth. This can happen because of the intangible nature of organizational innovation (Varis and Littunen 2010). Most SMEs develop product innovation because of higher profitability (Oke et al. 2007; Chetty and Stangl 2010). Morone and Testa (2008) in the study of the Italian manufacturing sector concludes that product innovation, process innovation, and organizational changes are significantly associated with organizational growth.

Nevertheless, there is no considerable relation to marketing innovation in firms' growth. Also, Ar and Baki (2011) reconfirm a positive influence of product and process innovation on firm performance based on the study done with SMEs located in Turkish science and technology parks. Lin and Chen (2007) emphasize the linkage between innovation development and increased firm sales; particularly, they state that organizational innovations (administrative one) play the most important role in total sales. Organizational innovation play a fundamental role in innovative capabilities and they often prepare a suitable milieu for other innovation types; thus, it is suggested that managers should pay greater attention to this type of innovation (Gunday et al. 2011). Besides that, marketing innovation is associated positively with sales growth 
in a study with data collected from the Norwegian hotel industry (Sandvik and Sandvik, 2003). Moreover, market innovation is significantly associated with organizational growth in SME furniture industries from Italy, Spain and Finland were emphasized by OteroNeira et al. (2009). Furthermore, Lin and Chen (2007) found that marketing innovations lead to higher firm sales by increasing product consumption.

Indeed, in the literature review, product and process innovation have a positive impact on firm performance, while the effect of marketing and organizational innovations in firm performance is not conclusive, as there has not been very much empirical research in this area. Therefore, the discussion leads to this hypothesis:

\section{Hypothesis 2: Product/process innovations are positively associated with sales growth.}

\section{Hypothesis 3: Organizational innovation is posi- tively associated with sales growth.}

\section{Hypothesis 4: Marketing innovation is positively associated with sales growth.}

\section{SMEs Growth}

The term firm growth was introduced in the 1930s, which was known as the Law of Proportionate Effect. It is also called Gibrat's rule of proportionate growth, used to determine firm growth, which does not depend on the firm size (Rosli and Sidek 2013). Growth is associated with the firm survival and achievement of organizational goals. It is measured in terms of employment, revenue, market share and product development (Pasanen 2007). Firm growth has gained interest among different academics mainly because it contributes to the economy through new job creation. The turnover of the firm is the most frequent measure of growth, which addresses taxation concerns, whereas the number of employees is another measure of growth, which addresses the job concerns and has to do with the working capacity. There is an interconnection between these two growth indicators within the context of SMEs, and they are used because of their visibility and simplicity to obtain within organizations (Storey 1994). Many firms use financial indicators, such as return on assets (ROA), return average annual occupancy rate, net profit after tax and return on investment (ROI) to measure growth (Rosli and Sidek 2013).

Some factors that lead to firm growth include entrepreneur's growth orientation, adequate firm resources for growth and the existence of a market opportunity for growth. The main influences of SMEs' growth are the background and access to resources of the entrepreneur(s), the firm itself, and the strategic decisions taken by the firm once it is trading (Storey 1994). This research paper tests some of the factors related to entrepreneurs and firms.

The first influential factor is entrepreneurs' characteristics, which have to do with the attributes of the person who establishes the firm and the key resources provided for firm creation. Personal characteristics of the business owners may contribute to the growth of the firm, such as motivation, education, and ownership/management experience, number of founders, ethnicity, age, and gender.

Motivation can influence on the strategic choices made by the business owners (Storey 1994). Woodward (2006) distinguishes necessity and opportunity entrepreneurs. Necessity entrepreneurs are those who decide to start-up to make a living as they do not find other opportunity choices for work, while opportunity entrepreneurs are those that are more closely to the classical idea of Schumpeter entrepreneurs, characterized by inventiveness, vision, and perception to discover opportunities in the market. According to Owualah (1990), the four most important motivations to start-up include the need for independence through self-employment, the market opportunity afforded by the business owner to develop a certain idea, higher financial returns and building up a business for the future. Another personal characteristic, as described by Storey (1994), is education, where educated business owners usually establish a firm in the discipline they have been educated and use several skills in business management. Human capital is significant for any organizations because of employees' qualifications and loyalty to a firm that leads to organizational success (Becker 1962 in Moog 2002). Becker's human capital theory makes a distinction between general and specific human capital. Common measures of general human capital include education, apprenticeship, and vocational training, while measures of specific human capital involve tacit skills and training related to a specific job that is less transferable, and have a narrow scope of applicability in the job. An entrepreneur who is educated and has a high amount of human capital is better prepared to lead a company, because of the efficiency in organizing and managing the firm processes, managing information and creating relationships with various partners for investment (Pfeiffer/Falk 1999 in Moog 2002). The business owners, who have prior experience, are likely to observe better growth-related opportunities and 
avoid pitfalls. Also, middle-aged owners have more potential to succeed because of the experience, credibility, energy, and availability of resources. Lastly, most studies have concluded that the gender of the business owner is not a significant factor in the growth behaviour of the firm (Storey 1994). This discussion leads to the following hypotheses:

Hypothesis 5: Entrepreneurs that establish a firm by catching opportunity is positively associated with sales growth.

Hypothesis 6: The type of education level of en-
trepreneurs is associated with sales growth.

Hypothesis 7: The work experience of entrepreneurs is positively associated with sales growth.

\section{Hypothesis 8: The age of entrepreneurs is nega- tively associated with sales growth.}

Hypothesis 9: The gender of entrepreneurs is associated with SME sales growth.

The second influential factor to growth in SMEs is firms' characteristics, which relate to the decisions made when starting a business. This is linked to the stages-of-growth model based on the intention and capabilities of business owners to grow. Some of the factors include age, sector, location, size and ownership form. This research paper included the following variables related to the firm. The finding that younger small firms grow faster than old ones is not conclusive due to the fact that in population analysis of US firms, there was a similar proportion of an increase in employment rate when comparing new and established firms. Firms operating in one sector may grow faster than in firms operating in another; therefore, it influences firm growth rates (Storey 1994). This discussion leads to the following hypotheses:

\section{Hypothesis 10: The age of the firm is positively as- sociated with sales growth.}

\section{Hypothesis 11: The type of industry: is associated with sales growth.}

Figure 1 shows a conceptual research model.

\section{Entrepreneurship under transition context}

Central and Eastern European countries faced the issue of transformation form centrally planned into market economies, which encouraged the growth of the private business sector (Smallbone and Welter, 2001). Entrepreneurship and SMEs have played a significant role in the labour reallocation among firms and industries in transition countries, and the recovery of these countries from recession into systemic change. In the phase of systemic change, the necessity-driven entrepreneurs offered goods and services in short supply to survive in the market. Then opportunity-driven entrepreneurs appeared who were focused on innovation activities, by searching for new products, new markets and new opportunities for long term growth

Figure 1. Conceptual Research Model

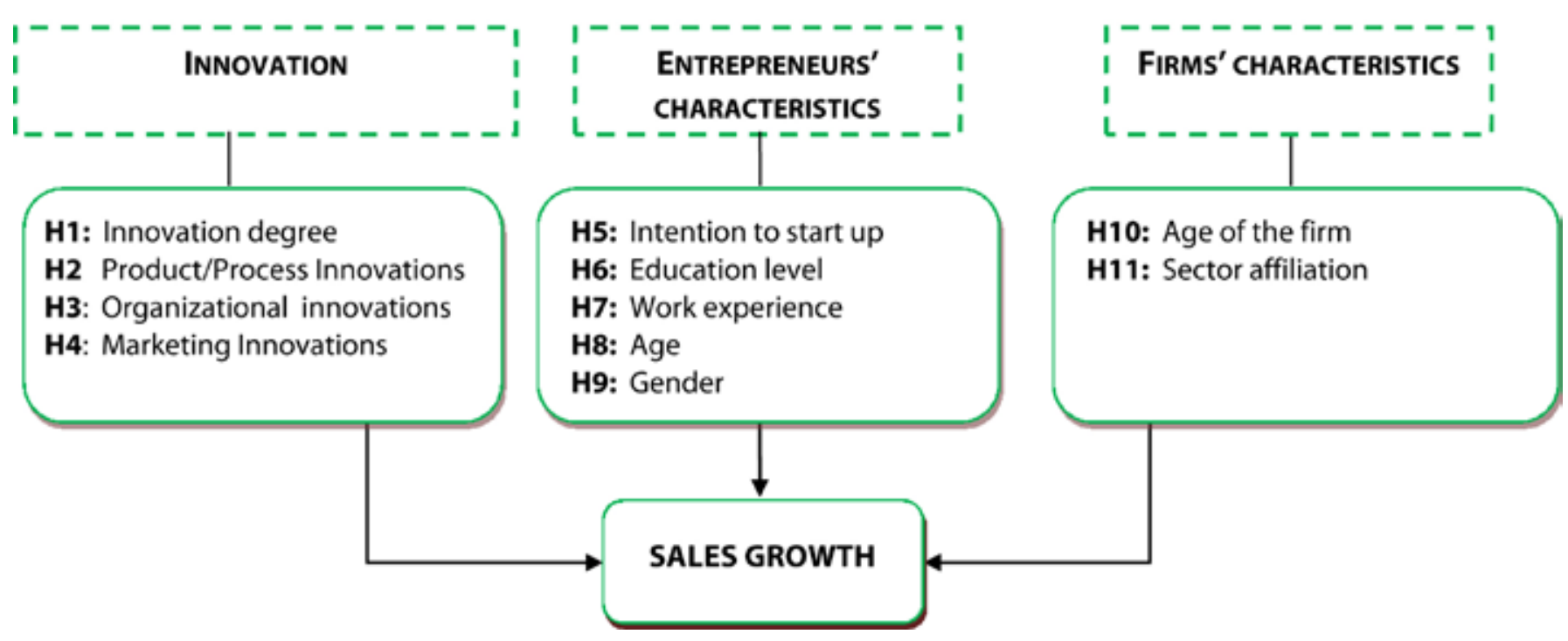

Source: Self devised 
and expansion (Krasniqi, 2012). Moreover, entrepreneurs in transition countries encounter various formal and informal institutional barriers, such as poor legal framework, property rights, government regulations, and administrative burdens (Hashi and Krasniqi, 2008). Entrepreneurs in transition countries were characterized with the uncertainty of supply and demand, as well as the transformation of old rules and regulations, which led to specific entrepreneurial aspirations and engagements which were different compared to developed market economies (Grilo and Thurik, 2006). Considering that these firms were created under different conditions with structural systemic changes, entrepreneurial behavior and development vary from those in developed market economies (Karlsson and Dahlberg, 2003). Stojcic and Hashi (2014) found that when compared to mature market economies, new EU member states and candidate countries have a lower probability to innovate, as they invest fewer resources and are less productive in transforming innovation inputs into innovation outputs. Moreover, changes in organizational routines are implemented at a slower rate in firms in mature market economies, leading to lower productivity (Hashi and Stojcic, 2013). The empirical results in a study of Hashi and Stojcic (2013), show no significant feedback of sales of new products and investment in innovation activities in market economies of Western Europe, while there is a negative effect from productivity to innovation output in transition economies due to their strong firms' specialization in labor-intensive products.

Kosovo is not an exception. The unemployment push and other reasons for massive dismissal of workers from firms influenced the dominance of shuttle-trade businesses, while the number of stable businesses was limited. Due to conflict and the war, the week institutional reform created more opportunities for necessity-driven entrepreneurs in Kosovo (Krasniqi, 2014). Large incumbent enterprises with market domination position and anticompetitive barriers tend to restrain entrepreneurial energy and initiative, by taking advantage of the weak institutional environment. Also, harm to the business environment is an informal economy with poor labour productivity, which has grown within Kosovo and makes establishing formal business very costly to operate. Thus, the informal economy hinders competition, and the firm performance does not reveal its real performance through competitive advantage rather than their ability to engage in the informal economy, tax avoidance and corruption (Krasniqi, 2012).

\section{RESEARCH METHODOLOGY}

This study uses empirical data gathered from 278 Small and Medium Enterprises through a Survey conducted by the Business Support Centre Kosovo (BSCK) for the year 2012, which provides information on the entrepreneurship and SMEs in Kosovo. Face to face interviews was conducted mainly with owners/managers or in some cases with financial managers. The sample of SMEs was selected randomly from the business register of the Ministry of Trade and Industry by the Agency for Business Registration through Excel and SPSS using the random command. Nevertheless, because of the unsatisfactory results of the representation of medium enterprises and manufacturing ones, stratification was applied to have a representation of both the size of the company and sectors of business activity. The sample includes SMEs within all the regions of Kosovo, stratified to the three main sectors, such as trade $(44 \%)$, production (13\%) and services (43\%) (BSCK 2013).

\section{Measures}

\section{Dependent variable}

The dependent variable is firm growth. Although a variety of measures have been used in the literature review, there is a lack of articles that have used sales as the dependent variable to measure firm growth. Thus, in this study, the sales variable is used as a measure of firm growth. In the questionnaire, respondents were asked whether the sales have increased or not in the past three years.

\section{Independent and control variables}

Literature suggests that (Miller and Friesen 1984; Wiklund et al. 2009; Krasniqi 2012) suggest that testing a large number of independent variables helps to come up with a more realistic image of growth phenomenon. The review of this literature revealed that the choice of variables in the existing empirical models on small firm growth is rather limited urging the need for a wider choice of variables. Thus, in this study, they are grouped into three components, such as innovation, entrepreneur and firm. Entrepreneur and firm components are control variables. Table 1 shows a detailed description of a list of explanatory variables. 


\section{Independent variables}

The first group of variables includes the most important explanatory variables related to innovation. It includes innovative degree, the introduction of new or substantial modification of products/services/processes, organizational innovation, and marketing innovation. In the empirical analysis, new to the firm variable indicates that the introduction of innovation is new to the firm, rather than new to the market (Yes=New to the firm, No=Otherwise). Also, through empirical analysis, it is measured whether or not the introduction of product/service innovation, organizational innovation, and marketing innovation have an impact on SMEs' growth ( $\mathrm{Yes}=1, \mathrm{No}=0)$.

\section{Control variables}

The second group represents variables related to entrepreneurs, such as entrepreneur intention to start up, as well as entrepreneurs' education, work experience, age, and gender. In the empirical analysis, the first variable is used to measure whether (or not) the main motivation was because they spotted a business opportunity and decided to act upon it and establish their own company ( $1=$ Yes, $0=\mathrm{No})$. In this study, a proxy for general human capital has been used the influence of the highest education level on organizational performance. The work experience variable is used to measure whether they have a university degree or not $(1=\mathrm{Yes}, 0=\mathrm{No})$. We control for gender (males $=1$, female $=0$ ), work experience and age of the

Table 1. Independent and Control Variables

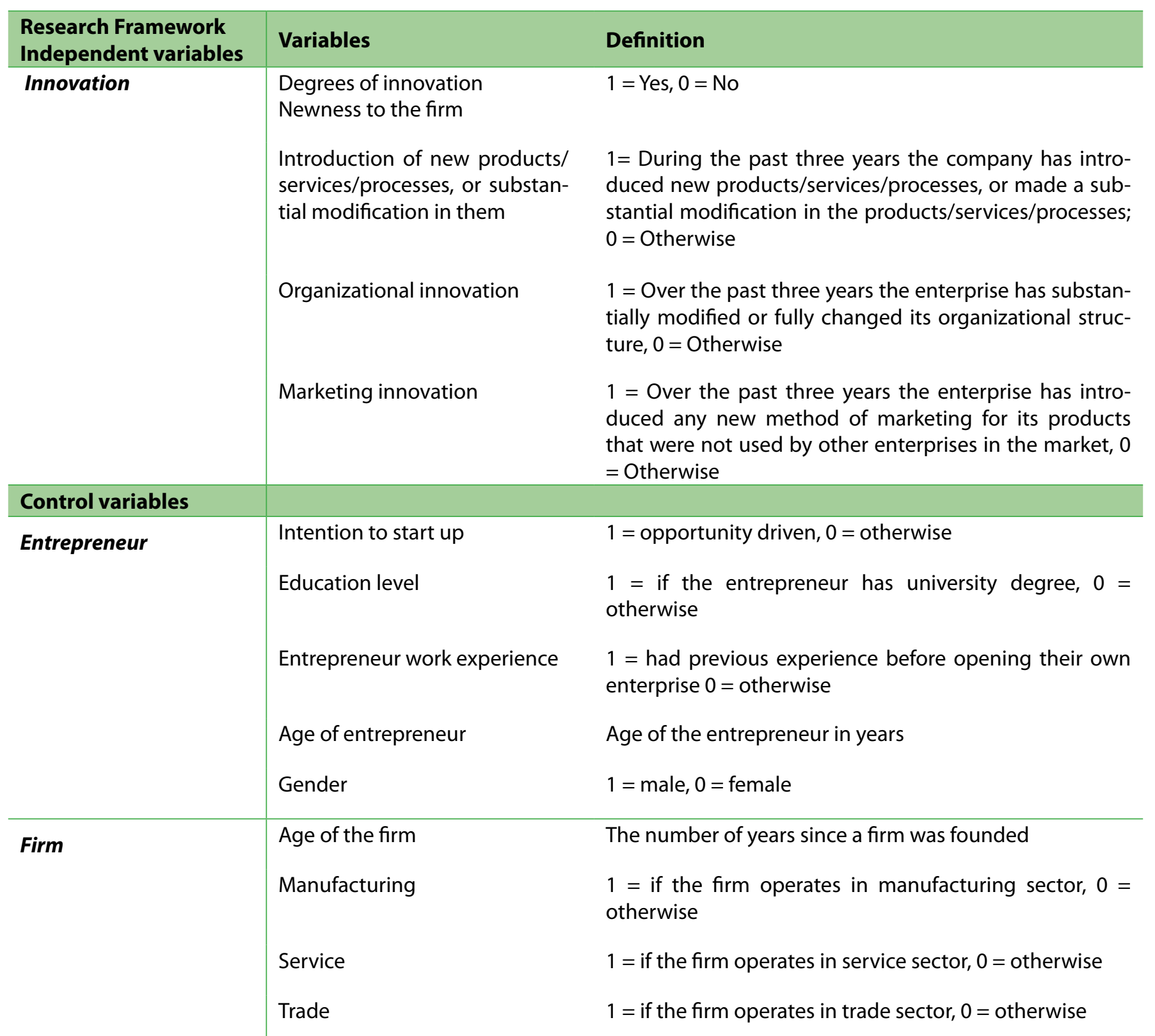


entrepreneur.

The third component includes variables related to the firm, such as firm age and sector affiliation. These are used as control variables that might influence firm growth. We also control for the industry sector, where three main sectors dummies are manufacturing, trade, and services. Moreover, the control variable, such as firm age is used to capture the effect on firm growth (Storey 1994).

\section{RESULTS AND DISCUSSION}

\section{Descriptive Statistics}

The descriptive statistics in Table 2 display that the average age of respondents in the sample is 37 years. The vast majority of respondents are males. A significant number of respondents have a university degree (about $40 \%$ ), and most of them have prior experience before opening the business. The average age of enterprise is 10 years, which shows that most of them have been established in the post-war period. The majority of firms were established in the trade sector, followed by service and manufacturing sectors with a lower number of firms. In general, the level of innovations in Kosovo is low, and most innovations are new to the firm; still, new or improved product/ service innovations are more likely to be developed by firms compared to organizational and marketing innovations which are conducted at a lower degree. Interestingly, the majority of respondents indicated that the main motivation to establish a firm was driven by market opportunities, rather than necessity.
Bivariate correlations for all variables have been included under consideration. It can be concluded that even though numerous correlation coefficients are significant at the 0.01 level (2-tailed test) and the 0.05 level (2-tailed test), multicollinearity will not affect our data results as most of the coefficients are sufficiently low compared to the absolute value which is a threshold smaller than 0.7 (Lind et al. 2000). Moreover, multicollinearity is tested by means of collinearity statistics, where the variance inflation factor (VIF) is a reciprocal of tolerance. Thus, bivariate correlations and VIFs show that the data does not show any significant multicollinearity because of relatively low correlation and none of VIFs is close to a cut-off threshold of 10. Because of this, all these variables can be initially included within the model (Kleinbaum et al. 2007).

\section{Logistic Model}

The logistic regression model was used to predict a dichotomous variable of firm growth from predictor variables. A dichotomous variable is a firm growth in terms of sales, coding 1 if sales grow, and 0 if there is no growth in sales. The independent variables comprise of those related to entrepreneur, firm and innovation characteristics. The discussion of the econometric logit model through SPSS is used to investigate which of the factors lead to firm growth in terms of sales.

Table 3 presents the results of logit estimates for SMEs' growth in terms of sales.

Table 2. Descriptive Statistics

\begin{tabular}{l|rrrrr}
\hline & $\mathrm{N}$ & Minimum & Maximum & $\begin{array}{c}\text { Mean } \\
\text { Deviation }\end{array}$ \\
\hline Opportunity driven start up motivation & 456 & 0 & 1 & 0.7193 & 0.44984 \\
Education level of entrepreneur & 486 & 0 & 1 & 0.4033 & 0.49106 \\
Prior experience of entrepreneur & 467 & 0 & 1 & 0.7259 & 0.44653 \\
Age of entrepreneur & 494 & 17 & 78 & 37.37 & 11.194 \\
Age of the entrepreneur squared & 494 & 289 & 6084 & 1521.605 & 922.5475 \\
Gender of entrepreneur & 493 & 0 & 1 & 0.846 & 0.3615 \\
Firm Age & 466 & 0 & 10.32 & 9.012 \\
Manufacturing sector & 410 & 0 & 1 & 0.1732 & 0.37886 \\
Service sector & 410 & 0 & 1 & 0.5049 & 0.48999 \\
Trade sector & 410 & 0 & 1 & 0.126 & 0.3322 \\
New or substantial modification of & 484 & 0 & 1 & 0.2 & 0.4007 \\
products/services/processes & 484 & 0 & 1 & 0.101 \\
Organizational innovation & 484 & 0 & 1 & 0.1 & 0.30038 \\
Marketing innovation & 400 & 0 & &
\end{tabular}


Table 3. Logit estimates for SMEs growth

\begin{tabular}{|c|c|c|c|c|c|c|c|}
\hline & & B & S.E. & Wald & df & Sig. & $\operatorname{Exp}(B)$ \\
\hline \multirow[t]{18}{*}{ Step 1a } & Innovation variables & & & & & & \\
\hline & New_to_the_firm & -1.247 & .638 & 3.815 & 1 & $.051^{* *}$ & .287 \\
\hline & Prod_innovation & .660 & .563 & 1.371 & 1 & .242 & 1.934 \\
\hline & Org_innovation & -.502 & .677 & .549 & 1 & .459 & .605 \\
\hline & Mkt_innovation & 1.727 & .642 & 7.238 & 1 & $.007^{* * *}$ & 5.623 \\
\hline & Entrepreneur characteristics & & & & & & \\
\hline & Opportunity_driven & .528 & .411 & 1.647 & 1 & .199 & 1.695 \\
\hline & Edu_entrep & .622 & .337 & 3.402 & 1 & $.065^{* *}$ & 1.863 \\
\hline & Experience_entrep & 1.151 & .425 & 7.353 & 1 & $.007^{* * *}$ & 3.162 \\
\hline & Age_entrep & .326 & .121 & 7.218 & 1 & $.007^{* * *}$ & 1.385 \\
\hline & Age_entrep_squared & -.004 & .002 & 6.963 & 1 & $.008^{* * *}$ & .996 \\
\hline & Gender_entrep(1) & -.034 & .438 & .006 & 1 & .938 & .966 \\
\hline & Firm characteristics & & & & & & \\
\hline & Firm_age & -.034 & .022 & 2.311 & 1 & .128 & .967 \\
\hline & Man_sec & -.834 & .655 & 1.620 & 1 & .203 & .434 \\
\hline & Serv_sec & -.449 & .671 & .448 & 1 & .503 & .638 \\
\hline & Trade_sec & -1.050 & .669 & 2.462 & 1 & .117 & .350 \\
\hline & Constant & -7.622 & 2.442 & 9.740 & 1 & .002 & .000 \\
\hline
\end{tabular}

*** Significant estimate at $1 \%$ level; ${ }^{* *}$ significant estimate at 5\%; ${ }^{*}$ significant estimate at $10 \%$ level

\section{The Innovation}

Innovation characteristics represent the first group of independent variables that influence firm performance, such as innovative degree, product/process innovation, organizational innovation, and marketing innovation.

The first hypothesis related to innovation degree (SMEs introduce more new to the firm products to achieve growth) is significant but negatively associated with firm growth. In this context, there are mixed results related to the innovation degree. SMEs are characterized by innovations that are incremental, or new to the firm, as they are characterized by limited resources in capital, personnel, and technology (Storey 1994; Woschke et al. 2016). Oke et al. (2006) found that SMEs tend to develop more incremental innovations, and this focus is related to firm growth in terms of sales. Nevertheless, in a study conducted in Dubai SMEs, the leading type of innovation was radical (Al-Ansari et al. 2013), which is in disagreement with previous authors that perceive SMEs, not as risk-takers as large enterprises, and only limited to incremental innovation. Srhoj and Zilic (2020) found that in a study of Croatia, limited liability firms, which are opened through grant schemes, have a lower potential to growth and survival, while unlimited liability firms have a more favourable survival profile. Nevertheless, the effectiveness of these grants schemes to ease the initial phase of a business start-up is improving throughout the years.

The second hypothesis related to product/process innovation is not supported. This empirical finding is not in line with literature review. It is probably because manufacturing sector is not developed to a high extent; thus, there are not many product innovations developed by SMEs in Kosovo. Various studies have examined the association of product innovation on firm growth, and most of them find a positive relationship (Bayus et al. 2003; Oke et al. 2007; Chetty \& Stangl 2010; Ar and Baki 2011; Rosli and Sidek 2013). On the other hand, some studies found a negative and statistically significant coefficient relationship between product innovation and their productivity (Stojcic and Hashi, 2014; Halpern and Murakozy, 2012). Other studies show a significant relationship between product, process and market innovations on firm growth, but no relationship between organizational innovation and firm growth (Hernandez-Espallardo and DelgadoBallester 2009). Nevertheless, in a study of Morone and Testa (2008), product innovation, process innovation, and organizational changes are significantly 
associated with organizational growth, while no considerable relationship between marketing innovation and firms' growth. Moreover, a strong relationship between marketing innovation and firm growth has been concluded in a study conducted by Sandvik and Sandvik, (2003) and Lin and Chen (2007). Also, there is a positive relationship between new product innovation and a larger share of high growth firms (Krasniqi and Desai 2016).

The third hypothesis related to organizational innovation has non-significant value. There are mixed results of organizational innovation. Some studies indicate a positive association between organizational innovation and firm growth (Oke et al. 2007; Lin and Chen 2007; Morone and Testa 2008; Chetty and Stangl 2010). Especially, Lin and Chen (2007) indicate a positive relationship between organizational innovation and firm growth, in terms of sales. Moreover, managers should play great attention to the organizational type, even though it is intangible, considering that it often has an impact on other types of innovation (Gunday et al. 2011, Mahmutaj et al. 2019). Organizational innovations positively affect the decision to innovate, leading to higher firms' efficiency and increasing employees' creativity (Stojcic and Hashi, 2014).

The fourth hypothesis related to marketing innovation is supported, suggesting that there is a positive association between marketing innovation and the firm's growth. There are mixed results related to marketing innovation. Some agree that changes in marketing can lead to higher sales (Lin and Chen 2007; Oke et al. 2007; Chetty and Stangl, 2010). Sandvik (2003) highlight no considerable relation of marketing innovation in firm growth. Stojcic and Hashi (2014) found that the elements of marketing innovation, such as an improved relationship with clients and suppliers or improved design has a positive influence on the firms' decision to innovate and thus improve their growth.

\section{The entrepreneur}

In this research model, the entrepreneur characteristics represent the first group of independent variables that influence firm performance.

The fifth hypothesis is related to the motivation of the entrepreneur to start up a business. This variable is not statistically significant; thus, it does not support the hypothesis. Segal et al. (2005) and Asah et al. (2015) argues that there is a predominance of business ownership driven by pull factors; thus, they are more likely to succeed and have a better chance of survival. Moreover, some authors have found a positive relationship between entrepreneurial motivations and firm growth (Verheul et al. 2010). Block and Wagner (2007) argue that entrepreneurs entering a business due to pull factors are more successful in business and they are characterized with higher earnings compared to those of necessity entrepreneurs.

There are mixed results related to entrepreneurial motivations in developing countries. For instance, for Vietnamese entrepreneurs, challenges and achievements are more important motivators than necessity and security (Swierczek and Ha 2003). Some other studies conclude that there are regional differences in Vietnam, where some entrepreneurs that come from the weaker economies are motivated by push factors related to job creation (Benzing et al. 2005). Another illustration is Romania, the strongest motivator for creating an enterprise is related to income needs (Benzing et al. 2005). On the other hand, in a more developed region of India, entrepreneurs are mainly motivated by pull factors, such as the desire for independence and autonomy (Benzing et al. 2005). Also, a study of SMEs in Kenya, Ghana, and Nigeria show that entrepreneurs in developing countries are motivated mostly by push factors, to increase their income and have job stability (Benzing and Chu 2009).

The sixth hypothesis related to the entrepreneur's educational level has significant value (0.065), suggesting that the education level of entrepreneurs is positively associated with firm growth. Gao and Hafsi (2015) argue that the higher the level of owner's education, the better is the outcome of innovation activities and firm growth. Moreover, Bhutta et al. (2008) found that education has a positive impact on the firm's performance. Akinboade (2015) suggests that SMEs' efficiency is affected by the level of education of owners. The results of a study of 575 SME owners show that there is an improved turnover growth with an increased level of owners' education.

The seventh hypothesis relates to entrepreneurs' prior work experience is supported, implying that for every one unit increase in years of experience, there is an increased likelihood to achieve firm sales by a factor of 1.151. Similarly, in the review of literature, it is argued that previous entrepreneurial experience plays a significant role in the firm's growth. The entrepreneurial experience with the goals, rewards, and methods of the particular area play a significant role in their perception and decision making. Moreover, those entrepreneurs with experience in the function of R\&D/engineering and marketing/sales often support more innovation strategies leading to organizational growth with new products and markets (Gao and Hafsi 2015). Similar results are found in another study by Krasniqi et al. (2008) who found that experience 
matters for firm growth.

The eighth hypothesis related to the age of the entrepreneur is not supported. Nevertheless, the entrepreneur age was squared to better find out the turning point, which shows until what age, the entrepreneur is capable of having a positive effect on firm growth. The logit estimates present a p-value of 0.08 , implying that the variable entrepreneur age squared is significant, but it is negatively associated with firm growth by -0.004 .

The following is the calculation of the turning point or the maximum of the function at the estimated equation entrepreneur age and entrepreneur age squared (Wooldridge, 2012, p.195). This is achieved at the coefficient on entrepreneur age over twice the absolute value of the coefficient on entrepreneur age squared. This measures the point where the effect of entrepreneur age becomes zero at about 40.8 (|0.326/ $\left(2^{*}-0.004\right) \mid=40.75$ years $)$. Entrepreneur age and its squared term at the start-up is significant and nonlinear, in the form of an inverted U-shaped. The effect of entrepreneur age on firm growth at the beginning is positive because entrepreneurs are young and have greater dynamism. The turning point when the entrepreneur age becomes negative is around 41 years. This is because entrepreneurs get older and their efforts and dynamism for growth decrease, suggesting that entrepreneurs older than 41 years have negative effects on firm growth.

Other studies found the entrepreneur age as a significant variable for firm growth. Previous research also shows that older top managers tend to be less likely to take risks and to invest in growth strategies compared to their younger counterparts (Hambrick and Mason 1984; Mudambi and Treichel 2005). Some of the explanations for this include that older executives have less physical and mental stamina and gave a psychological commitment to the status quo of the firm. They are less able to grasp new ideas and adapt to new behaviors, and sometimes their financial and career security is more important; thus, they try to avoid any risky action. Hence, the firm growth, in particular sales and earnings are associated with youthful entrepreneurs (Hambrick and Mason 1984). Moreover, young founders are better adapted to the new economies associated with the development of new technology, markets, metrics, and others, as they have a better understanding of these important aspects. When people get older, their flexibility decreases; and they try to maintain the status quo because of their resistance to change (Mudambi and Treichel 2005). Therefore, younger founders have individual characteristics, such as creativity, intuition, and ability to grasp new opportunities and take risks, which impacts firm growth. Moreover, another study concludes that the lower age of the entrepreneur has a positive impact on the firm's growth, considering that the strategic orientation of the older ones may be detrimental to firm growth (Colombelli 2015).

The ninth hypothesis related to the gender of an entrepreneur is not supported. The empirical results are similar to the findings of other authors in the literature review. There is no association of the gender of an owner with firm growth in terms of business sales (Akinboade 2015). Different experts suggest that female entrepreneurs have lower growth ambitions compared to males, because of scarce resources, time, and experience (Cliff 1998). In terms of sales growth, women entrepreneurs tend to perform worse than men (DuRietz and Henreksson 2000). Krasniqi (2009) states that gender has a positive impact on entrepreneurial involvement, with men being more likely to become entrepreneurs than women. Nevertheless, grant schemes on women entrepreneurship have a positive impact on firm survival. They help women entrepreneurs to gather more information and reduce risk aversion, which in turn increases investment opportunities (Srhoj et al. 2019).

Earlier studies show mixed results related to the gender of entrepreneurs and their effect on firm performance. Some studies conclude a positive effect, such as a positive relationship between return on asset (ROA) and the chance to have a woman to board for 1000 Fortune firms (Farrell and Hersch, 2005). Nevertheless, some studies confirm a negative association between females on board and firm growth (Shrader et al. 1997). Moreover, Thompson et al. (2009) indicate that women businesses are small and remain so, and they are more likely to manage a home-based business or operate a business on part-time basis, which gives them the flexibility to take care of their families.

\section{The firm}

In this model, the firm characteristics represent the second group of independent variables that influence firm performance, such as firm age, and sector of economic activity (manufacturing, service or trade).

The tenth hypothesis related to the age of the firm is not supported. Other studies show mixed results. According to Calantone et al. (2002), firm age has a positive impact on their performance. Nevertheless, other studies conclude that firm age is negatively and significantly correlated with firm growth (Krasniqi 2012; Colombelli 2015).

The eleventh hypothesis related to sectors is not 
supported. The results show that $\mathrm{H} 11 \mathrm{~A}, \mathrm{H} 11 \mathrm{~B}$, and $\mathrm{H} 11 \mathrm{C}$ are not supported due to the non-significance value $(p>0.01)$. Nowadays, there is a growing interest in the topics of innovation in service firms. The service sector took a central role in developed and developing economies since the year of 2000 (Bhatnagar and Gopalaswamy, 2017). Previous studies largely focus on manufacturing firms; nevertheless, it is not possible to predict patterns and understandings of innovation services in service firms through studies in manufacturing firms (Menor et al. 2002). Some studies show the importance of innovation in the service sector (Rodríguez-Gutiérrez et al. 2015; Gianiodis et al. 2014). Yang et al. (2014) discuss that service-oriented SMEs can provide differentiated service products through internal R\&D to expand market share, or they can develop a low-cost competitive advantage by providing continuous innovation. The firms in the manufacturing sector are more likely to be engaged in process innovation than in product innovation, as manufacturing firms tend to use more technologically advanced production processes when compared to other sectors, such as trade and services (Krasniqi and Kutllovci 2008). Still, Thornhill (2006) emphasizes innovation is more common for those firms where there is an increased industry dynamism, irrespective of which type of industry they are operating.

\section{Robustness check}

As a robustness check or as a means of evaluating the appropriateness of the logistic regression model, a series of logit estimation were analysed. The findings, statistical significance, and Coefficient from logit estimation demonstrate that they are closed to the full model of logistic regression.

The models are presented in Table 4. The first model includes variables related to entrepreneurs, such as education, experience, and gender of the entrepreneur. The variable entrepreneur education is statistically significant, which present that the likelihood that firm growth increase by $44.8 \%$. Similarly, entrepreneur experience is statistically significant, and positively affects firm growth with B of $86 \%$. On the other hand, the variable of gender is not significant. In the second baseline model are added variables related to firm characteristics, such as firm age and the trade sector. The firm age is not significant, while the trade sector is significant, and decreases the likelihood of firm growth by $42.5 \%$. Yet, the variables related to entrepreneurs remain significant and positively affect firm growth, similar to the first baseline model. In the third baseline model were added variables related to innovation, such as organizational innovation, marketing innovation and new to the firm innovation. The variable organizational innovation is

Table 4. Various specifications of the Logit model for firm growth in terms of sales

(1)

\section{Logit estimates}

\section{Entrepreneur characteristics}

\begin{tabular}{|c|c|c|c|c|c|c|}
\hline Edu_entrep & .448 & $.050^{* *}$ & .461 & $.069 *$ & .472 & $.106^{*}$ \\
\hline Experience_entrep & .860 & $.003^{* * *}$ & .720 & $.018^{* *}$ & 1.148 & $.002^{* *}$ \\
\hline Gender_entrep(1) & .199 & .522 & -.056 & .870 & -.090 & .819 \\
\hline \multicolumn{7}{|l|}{ Firm characteristics } \\
\hline Firm_age & & & -.014 & .322 & -.029 & $.090^{*}$ \\
\hline Trade_sec & & & -.425 & $.089 *$ & -.430 & .130 \\
\hline \multicolumn{7}{|c|}{ Innovation variables } \\
\hline Org_innovation & & & & & -.267 & .667 \\
\hline Mkt_innovation & & & & & 1.756 & $.002^{* * *}$ \\
\hline New_to_the_firm & & & & & -.941 & $.065^{*}$ \\
\hline \multicolumn{7}{|l|}{ Model fit } \\
\hline $\mathrm{n}$ & \multicolumn{2}{|c|}{415} & \multicolumn{2}{|c|}{341} & \multicolumn{2}{|c|}{296} \\
\hline-2 log-likelihood & \multicolumn{2}{|c|}{465.192} & \multicolumn{2}{|c|}{388.719} & \multicolumn{2}{|c|}{312.188} \\
\hline$x^{2}$ & \multicolumn{2}{|c|}{2.077} & \multicolumn{2}{|c|}{21.071} & \multicolumn{2}{|c|}{10.482} \\
\hline Nagelkerke R2 & \multicolumn{2}{|c|}{0.051} & \multicolumn{2}{|c|}{0.053} & \multicolumn{2}{|c|}{0.146} \\
\hline $\begin{array}{l}\text { Overall percentage } \\
\text { correct }\end{array}$ & \multicolumn{2}{|c|}{73.5} & \multicolumn{2}{|c|}{72.4} & \multicolumn{2}{|c|}{73.6} \\
\hline
\end{tabular}

(2)

(3)

B

Sig.

B

Sig.

B Sig. . 
not significant. The variable marketing innovation is statistically significant and increases the likelihood of firm growth by $175.6 \%$. Similarly, new to the firm innovation is statistically significant but decreases the likelihood of firm growth by $94.1 \%$. The variables related to entrepreneurs remain significant and positively affect firm growth, similar to in the first baseline model. Nevertheless, variables related to firm characteristics present minor changes about their significance. In this model, the variable firm age is significant and negatively affects firm growth, while the trade sector is not significant, even though the $p$-value is not much larger than 0.1. It is 0.13 .

The results show that entrepreneur education, experience, marketing innovation and new to the firm variables are statistically significant in three models, nearly the same as in the full model. The results are robust with the previously estimated logistic model as shown in Table 3. Nevertheless, the variable firm age is significant only in the third baseline model and the trade sector is statistically significant in the second baseline model, while they are not significant in the full model. Yet, there are no substantial differences; thus, it can be concluded the appropriateness of the logistic regression model for this study.

Regarding the fit statistics, all models appear to fit well with the data. The value of the Nagelkerke $R^{2}$ ranges from 0.051 to 0.146 for the baseline models to 0.217 for the full model, suggesting that the predictors explain a reasonable amount of the variation between firms having or having not achieved sales growth. Besides, the different estimated models show an acceptable predictive power, with more than $70 \%$ of predictions.

\section{CONCLUSIONS}

This paper investigates innovation at the level of SMEs and their impact on firm growth in the local Kosovo market context across three sectors: services, manufacturing, and trade. The data were analysed using a logistic regression analysis. The study and its hypothesized conceptual model draw a combination of areas of recent research, such as the theory of innovative enterprise and resource-based view, which are adjusted in the context of this investigation. The findings confirm the hypotheses that marketing innovation is positively associated with firm growth, while new to the firm products is negatively associated with firm growth. Nevertheless, product/process and organizational innovations resulted to be not significant. In the questionnaire, the SMEs were asked whether they have introduced product/process innovation; thus, these two types of innovations have been grouped, and it cannot be observed how many SMEs have introduced only product innovations, or process one. Moreover, the literature review findings indicate that product innovation has an impact on firm growth, while there are mixed results for organizational and marketing innovations. Future studies should treat the association of product/process innovations on firm growth, separately.

The identification of different hypotheses is a distinctive contribution as they create a conceptual framework, allowing for the understanding of complex relationships between the various factors related to entrepreneur, firm and innovations across three sectors, such as service, trade, and manufacturing. These variables were not considered altogether in previous studies; rather, researchers have focused only on some of them. Thus, they provide a holistic framework for future studies in innovation and SMEs growth. To the researchers' knowledge, this is the first empirical study of Kosovo SMEs in the service, trade and manufacturing sectors that investigates firm, entrepreneur and innovation dimensions within firm growth.

Besides consolidating the existing theory on the significance of innovation which explains firm growth variability, the findings also inform SMEs and policymakers that innovation is a considered a crucial factor in entrepreneurial activities. The empirical findings reveal insights into Kosovo SMEs, which shows that innovation characteristics can improve firm growth. This might further encourage SME managers to give higher efforts and try to develop different innovative ideas by encouraging employees to look for new knowledge and skills outside their tasks. Due to the high innovation costs, SMEs face challenge in terms of resources, personnel and R\&D expenditures; nevertheless, given the turbulent environment, SMEs should carefully find information about market demands and trends before making decision to innovate. As a future research can be decision making process to develop innovation.

Moreover, policymakers might be able to use these research findings as valuable input in creating regulations and introducing measures for promoting innovation activities of SMEs as an essential prerequisite for strengthening the growth potentials of the Kosovo economy. To achieve higher sales from new products, SMEs should carefully consider collaborative and developmental relationships with state-owned innovation procurement offices and other Public Procurement for Innovation stakeholders (Stojcic, Srhoj and Coad 2020). Considering that innovation is very important for firm growth, Stojcic and Hashi (2014) highlight that new EU member states and candidate countries should pay more attention to firms' 
innovation behavior through cohesion policy and other measures. Public support for innovation activities is relevant in the context of transition countries, considering that they lack technological and managerial capabilities toward the development of $R \& D$ for innovation (Alam et al. 2008). Other measures include export-oriented close-to-market grants for SMEs in form of consulting vouchers, which would help to penetrate foreign markets with innovative products (Srhoj and Walde 2020). Indeed, there are positive outcomes of the public grants on firm-survival, employment, tangible/fixed assets, and sales/turnover (Dvoulety, Srhoj and Pantea 2020). Moreover, to test the effectiveness of innovation development within SMEs, a future study could investigate companies over time from the initial stage to the full development of innovation.

\section{REFERENCES}

Akinboade, A. O. 2015. Determinants of SMEs growth and performance in Cameroon's central and littoral provinces' manufacturing and retail sectors. African Journal of Economic and Management Studies 6 (2) 183-196.

Al-Ansari, Y. Pervan, S. and Xu, J. 2013. Innovation and business performance of SMEs: the case of Dubai. Education, Business and Society: Contemporary Middle Eastern Issues 6 (3/4) 162-180.

Ar, I. M. and Baki, B. 2011. Antecedents and Performance Impacts of Product versus Process Innovation: Empirical Evidence from SMEs Located In Turkish Science and Technology Parks. European Journal of Innovation Management 14 (2) 172-206.

Asah, F. Fatoki, O. O. and Rungani, E. 2015. The impact of motivations, personal values and management skills on the performance of SMEs in South Africa. African Journal of Economic and Management Studies 6 (3) 308-322.

Atuahene-Gima, K, (1996). Market orientation and innovation. Journal of Business Research 35 (2) 93-103.

Baer, M. and Frese, M. 2003. Innovation is not enough: climates for initiative and psychological safety, process innovations, and firm performance. Journal of Organisational Behavior 24 (1) 45-68.

Bayus, B. L. Erickson, G. and Jacobson, R. 2003. The Financial Rewards of New Product Introductions. Management Science 49 (2) 197-210.

Benzing, C. and Chu, M. H. (2009). A comparison of the motivations of small business owners in Africa. Journal of Small Business and Enterprise Development 16 (1) 60-77.

Benzing, C. Chu, H.M. and Callanan, G. 2005. Regional comparison of the motivation and problems of Vietnamese entrepreneurs. Journal of Developmental Entrepreneurship 10 (1) 3-27.
Bhatnagar, N. and Gopalaswamy, A. 2017. The role of a firm's innovation competence on customer adoption of service innovation. Management Research Review 40 (4) 378-409.

Block, J.H. and Wagner, M. 2007. Opportunity recognition and exploitation by necessity and opportunity entrepreneurs: empirical evidence from earnings equations. in Solomon, G.T. (Ed.), Proceedings of the Sixty-Sixth Annual Meeting of the Academy of Management, ISSN 1543-8643, Philadelphia.

BSCK. 2013. Entrepreneurship and Small Business Development in Kosovo in 2012. http://www.bsckosovo.org/publikimet/20140205055101250.pdf (accessed October 15, 2018).

Calantone, R.J. Cavusgil, S.T. and Zhao, Y. 2002. Learning orientation, firm innovation capability, and firm performance. Industrial Marketing Management 31 (6) 515-524.

Chandler, G.N. and Hanks, S.H. 1994. Market attractiveness, resource-based capabilities, venture strategies, and venture performance. Journal of Business Venturing 9 (4) 331-349.

Chetty, S.K. and Stangl, L. M. 2010. Internationalization and innovation in a network relationship context. European Journal of Marketing 44 (11/12) 1725-1743.

Cliff, J.E. (1998) Does one size fit all? Exploring the relationship between attitudes towards growth, gender, and business size. Journal of Business Venturing 13 (6) 523-542.

Colombelli, A. 2015. Top management team characteristics and firm growth: Evidence from a sample of listed companies. International Journal of Entrepreneurial Behavior and Research 21 (1) 107-127.

Damanpour, F. and Evan, W.M. 1984. Organisational innovation and performance: the problem of organisational lag. Administrative Science Quarterly 29 (3) 392-409.

Deshpande, R. Farley, J.U. and Webster Jr., F. 1993. Corporate culture, customer orientation, and innovativeness in Japanese firms: a quadrate analysis. Journal of Marketing 5 (1) 23-27.

Dewar, R.D. and Dutton, J.E. 1986. The adoption of radical and incremental innovations: an empirical analysis. Management Science 32 (11) 1422-1433.

DuRietz, A. and Henreksson, M. 2000. Testing the female underperformance hypothesis. Small Business Economics 14 (1) 1-10.

Dvouletý, O., Srhoj, S. and Pantea, S. 2020. Public SME grants and firm performance in European Union: A systematic review of empirical evidence. Small Business Economics $1-21$

Evans, J. S. 1991. Strategic Flexibility for High Technology Manoeuvres: A Conceptual Framework. Journal of Management Studies 28 (1) 69-89. 
Farrell, K.A. and Hersch, P.L. 2005. Additions to corporate boards: the effect of gender. Journal of Corporate Finance 11 (1) 85-106.

Freeman, C. 1982a. The Economics of Industrial Innovation, second edition, Cambridge (Mass.): MIT Press.

Gao, Y. and Hafsi, T. 2015. R \& D spending among Chinese SMEs: the role of business owners' characteristics. Management Decision 53 (8) 1714-1735.

Garcia, R. and Calantone, R. 2002. A critical look at technological innovation typology and innovativeness terminology: a literature review. Journal of Product Innovation Management 19 (2) 110-132.

Garg, V.K., Walters, B.A. and Priem, R.L. 2003. Chief executive scanning emphases, environmental dynamism, and manufacturing firm performance. Strategic Management Journal 24 (8) 725-744.

Geroski, P, Machin, S. and Van Reenen, J. 1993. The Profitability of Innovating Firms. RAND Journal of Economics 24 (2) 198-211.

Gianiodis, P.T. Ettlie, J.E. and Urbina, J.J. 2014. Open service innovation in the global banking industry: inside-out versus outside-in strategies. The Academy of Management Perspectives 28 (1) 76-91.

Grilo, I. M. and Thurik A. R. 2006. Entrepreneurship in the EU: To Wish and not to be. Small Business Economics 26 305-318.

Gunday, G. Ulusoy, G. Kilic, K. and Alpkan, L. 2011. Effects of innovation types on firm performance. International Journal of Production Economics 133 (2) 662-676.

Halpern, L. and Murakozy, B. 2012. Innovation, Productivity and Exports: the Case of Hungary. Economics of Innovation and New Technology 21 (2) 151-173.

Hambrick, D. and Mason, P. 1984. Upper echelons: the organization as a reflection of its top managers. The Academy of Management Review 9 (2) 193-206.

Han, J.K. Kim, N. and Srivastava, R.K. 1998. Market orientation and organizational performance: is innovation a missing link? Journal of Marketing 62 (4), 30-45.

Hashi, I. and Krasniqi, B. 2011. Entrepreneurship and SME growth: evidence from advanced and laggard transition economies. International Journal of Entrepreneurial Behavior \& Research 17 (5) 456-487.

Hashi, I. and Stojcic, N. 2013. The impact of innovation activities on firm performance using a multi-stage model: Evidence from the Community Innovation Survey 4. Research Policy 42 (2) 353-366.

Hernández-espallardo, M. and Delgado-ballester, E. 2009. Product innovation in small manufacturers, market orientation and the industry's five competitive forces: Empirical evidence from Spain. European Journal of Innovation Management 12 (4) 470-491.

Hult, G.T. and Ketchen Jr. D.J. 2001. Does market orientation matter? A test of the relationship between positional advantage and performance. Strategic Management Journal 22 (9) 899-906.

Ittner, C.D. and Larcker, D.F. 1997. The performance effects of process management techniques. Management Science 43 (4) 522-534.

Jutla, D. Bodorik, P. and Dhaliqal, J. 2002. Supporting the ebusiness readiness of small and medium-sized enterprises: approaches and metrics. Internet Research: Electronic Networking Applications and Policy 12 (2) 139-64.

Kaplan, J. and Warren, A. 2007. Patterns of Entrepreneurship, New Jersey: John Wiley \& Sons, Inc.Karlsson, C. and Dahlberg, R. Entrepreneurship. 2003. Firm Growth and Regional Development in the New Economic Geography: Introduction. Small Business Economics 21 (2) 73-76.

Kleinbaum, D.G. Kupper, L.L. and Muller, K.E. 2007. Applied Regression Analysis and Other Multivariable Methods, Duxbury Press, Boston, MA

Knott, A.M. 2001. The dynamic value of hierarchy. Management Science 47 (3) 430-448.

Krasniqi, A, B. 2012. Entrepreneurship and small business development in Kosovo, New York, US: Nova Science Publisher.

Krasniqi, B. 2009. Personal, household and business environmental determinants of entrepreneurship. Journal of Small Business and Enterprise Development 16 (1) 146-166.

Krasniqi, B. 2014. Characteristics of self-employment: A refuge from unemployment or road to entrepreneurship. Small Enterprise Research 21 33-53.

Krasniqi, B. 2012. Building an Expanded Small Firm Growth Model in a Transitional Economy: Evidence on Fast Growing Firms. Journal of East-West Business 18 (3) 231-273.

Krasniqi, B. and Desai, S. 2016. Institutional drivers of highgrowth firms: country-level evidence from 26 transition economies. Small Business Economics 47 (4) 1075-1094.

Krasniqi, B. and Kutllovci, E. 2008. Determinants of innovation: evidence from Czech Republic, Poland and Hungary. International Journal Technoentrepreneurship 1 (4) 378-404.

Langley, D.J. Pals, N. and Ort, J.R. 2005. Adoption of Behaviour: Predicting Success for Major Innovations. European Journal of Innovation Management 8 (1) 56-78.

Lee, S. Park, G. Yoon, B. and Park, J. 2010. Open innovation in SMEs-An intermediated network model. Research Policy 39 (2) 290-300.

Lind, A.D. Mason, D.R. and Marchall, G.W. 2000. Basic Statistics for Business and Economics, 3rd ed., Irwin McGraw-Hill, Boston.

Li, H. and Atuagene-Gima, K. 2001. Product innovation strategy and the performance of new technology ventures in China. Academy of Management Journal 44 (6) 1123-1134. 
Lin, C.Y. and Chen, M.Y. 2007. Does innovation lead to performance? An empirical study of SMEs in Taiwan. Management Research News 30 (2) 115-132.

Mahmutaj, L. R. Ramosaj, B. and Krasniqi, B. 2019. Exploring Driving Factors and Challenges of Innovation in Service Firms: Evidence from Kosovo. International Journal of Technological Learning, Innovation and Development 11 (3) 215-244.

McGrath, R.G. Tsai, M.H. Venkataraman, S. and MacMillan, I.C. 1996. Innovation, competitive advantage and rent: a model and test. Management Science 42 (3) 389-403.

Menor, L.J. Tatikonda, M.V. and Sampson, S.E. 2002. New service development: areas for exploitation and exploration. Journal of Operations Management 20 (2) 135-157.

Miller, D. and Friesen, P. H. 1984. A longitudinal study of the corporate life cycle. Management Science 30 (10) 1161-1183.

Moog, P. 2002. Human Capital and its Influence on Entrepreneurial Success. Historical Social Research 27 (4) 157-180.

Morone, P. and Testa, G. 2008. Firms Growth, Size and Innovation an Investigation Into: The Italian Manufacturing Sector. Economics of Innovation and New Technology, Taylor and Francis Journals 17 (4) 311-329.

Mudambi, R. and Treichel, M.Z. 2005. Cash crisis in newly public Internet based firms: an empirical analysis. Journal of Business Venturing 20 (4) 543-571.

North, D. and Smallbone, D. 2000. The innovativeness and growth of rural SMEs during 1990s. Regional Studies 34 (2) 145-57.

OECD. 2005. OSLO Manual: Guidelines for collecting and interpreting innovation data, $3^{\text {rd }}$ edition. OECD Publishing, Paris.

Oke. A. Burke, G. and Myers, A. 2007. Innovation types and performance in growing UK SMEs International Journal of Operations \& Production Management 27 (7) 735-753.

Otero-Neira, C. Lindman, M. T. and Fernández, M. J. 2009. Innovation and Performance in SME Furniture Industries: An International Comparative Case Study. Marketing Intelligence \& Planning 27 (2) 216-232.

Owualah, S. I. 1990. Venturing Into Small Business in a Developing Economy: Motivations and Constraints. Savings and Development 14 (4) 415-424.

Pasanen, M. 2007. SME Growth Strategies: Organic Or NonOrganic? Journal of Enterprising Culture 15 (4) 317-338.

Pullen, A.J.J. De Weerd-Nederhof, P.C. Groen, A.J. Song, M. and Fisscher, O.A.M. 2009. Successful Patterns of Internal SME characteristics leading to high overall innovation performance. Creativity and Innovation Management 18 (3) 209-223.

Rodríguez-Gutiérrez, M.J. Moreno, P. and Tejada, P. 2015. Entrepreneurial orientation and performance of SMEs in the services industry. Journal of Organizational Change Management 28 (2) 194-212.
Rosli, M.M. and Sidek, S. 2013. The Impact of Innovation on the Performance of Small and Medium Manufacturing Enterprises: Evidence from Malaysia. Journal of Innovation Management in Small \& Medium Enterprise 2013 (2013) 794-809.

Salavou, H. and Lioukas S. 2003. Radical product innovations in SMEs: the dominance of entrepreneurial orientation. Creative and Innovation Management 12 (2) 94-108.

Sandvik, I. L. and Sandvik, K. 2003. The Impact of Market Orientation on Product Innovativeness and Business Performance. International Journal of Research in Marketing 20 (4) 355-76.

Segal, G. Borgia, D. and Schoenfeld, J. 2005. The motivation to become an entrepreneur International Journal of Entrepreneurial Behaviour and Research 11 (1) 42-57.

Shrader, C.B. Blackburn, V.B. and Iles, P. 1997. Women in management and firm financial performance: an exploratory study. Journal of Managerial Issues 9 (3) 355-372.

Singh, R.K. Garg, S.K. and Deshmukh, S.G. 2010. The competitiveness of SMEs in a globalized economy: observations from China and India. Management Research Review 33 (1) $54-65$.

Smallbone, D and Welter, F. (2001). The Distinctiveness of Entrepreneurship in Transition Economies. Small Business Economics 16 (4) 249-262.

Srhoj, S. and Zilic, I. 2020. "Fine...I'll do it myself": Lessons from self-employment grants in a long recession period. Radni materijali EIZ-a 2-38.

Srhoj, S. Škrinjarić, B. Radas, S., and Walde, J. 2019. Closing the Finance Gap by Nudging: Impact Assessment of Public Grants for Women Entrepreneurs. Radni materijali EIZ-a (2) 5-41.

Srhoj, S. and Walde, J. 2020. Getting ready for EU Single Market: The effect of export-oriented grant schemes on firm performance. Structural Change and Economic Dynamics 52 279-293.

Stojcic, N. and Hashi, I. 2014. Firm Productivity and Type of Innovation: Evidence from the Community Innovation Survey 6. Croatian Economic Survey. The Institute of Economics, Zagreb 16 (2) 121-14.

Stojcic, N., Srhoj, S. and Coad, A. 2020. Innovation procurement as capability-building: Evaluating innovation policies in eight Central and Eastern European countries. European Economic Review, 121, issue C.

Storey, D. 1994. Understanding the Small Business Sector, London: Routledge.

Subramanian, A. and Nilakanta, S. 1996. Organisational innovativeness: exploring the relationship between organisational determinants of innovation, types of innovations, and measures of organisational performance. Omega 24 (6) 631-647.

Swierczek, F. and Ha, T.T. 2003. Motivation, entrepreneurship and the performance of SMEs in Vietnam. Journal of Enterprising Culture 11 (1) 47-68. 
Thompson, P. Jones-Evans, D. and Kwong, C. 2009. Women and home-based entrepreneurship, evidence from the United Kingdom. International Small Business Journal 27 (2) 227-239.

Thornhill, S. 2006. Knowledge, innovation and firm performance in high- and low-technology regimes. Journal of Business Venturing 21 (5) 687-703.

Varis, M. and Littunen, H. 2010. Types of Innovation, Sources of Information and Performance in Entrepreneurial SMEs. European Journal of Innovation Management 13 (2) 128-154.

Verheul, I. Thurik, R. Hessels, J. and Van der Zwan, P. 2010. Factors influencing the entrepreneurial engagement of opportunity and necessity entrepreneurs. Scientific Analysis of Entrepreneurship and SMEs 11 (1) 1-23.

Wan, D. Ong, C. H. and Lee, F. 2005. Determinants of firm innovation in Singapore. Technovation 25 (3) 261-268.

Wiklund, J. Patzelt, H. and Shepherd, D. A. 2009. Building an integrative model of small business growth. Small Business Economics 32 (4) 351-374.

Wilson, C. N. and Stokes, D. 2005. Managing creativity and innovation: The challenge for cultural entrepreneurs. Journal of Small Business and Enterprise Development 12 (3) 366-378.
Wooldridge, J.M. 2012. Introductory Econometrics: A Modern Approach, $5^{\text {th }}$ ed., Mason: South-Western.

Woodward, R. 2006. Knowledge Based Entrepreneurship in two transition countries. European Association for Comparative Economics Studies (EACES) 9th Bi-Annual Conference: Development Strategies - A comparative view. University of Brighton Business School.

World Bank. 2013. Western Balkans Regional R\&D Strategy for Innovation. Available at: http://www.worldbank. org/content/dam/Worldbank/document/eca/WesternBalkans-R\&D-Kosovo.pdf (accessed February 12, 2019).

Woschke, T. Haase, H. and Kratzer, J. 2017. Resource scarcity in SMEs: effects on incremental and radical innovations. Management Research Review 40 (2) 195-217.

Yang, H. Song, H. M. and Yu, A. P. 2014. Theoretical analysis and empirical study on competitive advantages of service-oriented manufacturing-based on the data of 200 manufacturers in Jiangsu province. Management Review 26 (3) 89-99.

Yang, J. 2010. The knowledge management strategy and its effect on firm performance: a contingency analysis. International Journal of Production Economics 125 (2) 215-223. 